ARTIGO

COIttps://doi.org/10.22481/praxisedu.v15i34.5804

\title{
SPECIFIC FEATURES OF LIFE ORIENTATIONS AMONG STUDENTS AND THEIR INTERRELATION WITH PROFESSIONAL FORMATION
}

\author{
CARACTERÍSTICAS ESPECÍFICAS DE LAS ORIENTACIONES DE LA VIDA ENTRE \\ LOS ESTUDIANTES Y SU INTERRELACIÓN CON LA FORMACIÓN PROFESIONAL
}

\author{
CARACTERÍSTICAS ESPECÍFICAS DAS ORIENTAÇÕES PARA A VIDA ENTRE \\ ESTUDANTES E SUA INTER-RELAÇÃO COM A FORMAÇÃO PROFISSIONAL
}

\author{
Galina S. Goloshumova \\ Moscow Pedagogical State University, Moscow - Russia \\ Olga V. Gribkova \\ Moscow City University, Moscow - Russia \\ Alexey V. Kidinov \\ Russian State Social University, Moscow - Russia
}

Muliat M. Tkhugo

National Research University, Moscow - Russia

Oxana E. Chernova

RUDN University, Moscow - Russia

Natalia N. Telysheva

Moscow City University, Moscow -Russia

Emilia R. Agadzhanova

Ulyanovsk State University, Ulyanovsk - Russia

Resumo: O autor deste artigo considera um estudo empírico das orientações de vida dos estudantes e sua inter-relação com a formação profissional. Os principais objetivos do estudo são: conduzir a análise teórica das orientações de vida; compor um bloco de técnicas psicodiagnósticas para estudar orientações de vida entre estudantes de vários programas de estudo ;. O significado prático do estudo consistiu na compilação de um bloco de técnicas de psicodiagnóstico que podem ser usadas para diagnosticar as orientações de vida de uma pessoa 
e a esfera de valor-significado. Além disso, com base nos dados obtidos, é possível desenvolver suporte corretivo para orientações de vida e características pessoais e pessoais relacionadas da pessoa.

Palavras-chave: Análise teórica; Orientações de vida de uma pessoa; Modelo situacionalmente integral da personalidade de uma pessoa; Orientações de sujeito a objeto; Plano de vida inconsciente.

Abstract: The author of this paper considers an empirical study of students' life orientations and their interrelation with professional formation. The major objectives of the study are: to conduct the theoretical analysis of life orientations; to compose a block of psychodiagnostic techniques for studying life orientations among students of various programs of study;. The practical significance of the study consisted in compiling a block of psychodiagnostic techniques that can be used to diagnose both the life orientations of a person and the valuemeaning sphere. Also, on the basis of the data obtained, it is possible to develop corrective support for life orientations and related individual-personal characteristics of the person .

Keywords: Theoretical analysis; Life orientations of a person; Situationally integral model of a person's personality; Subject-object orientations; Unconscious life plan.

Resumen: El autor de este artículo considera un estudio empírico de las orientaciones de vida de los estudiantes y su interrelación con la formación profesional. Los principales objetivos del estudio son: realizar el análisis teórico de las orientaciones de la vida; componer un bloque de técnicas de psicodiagnóstico para estudiar las orientaciones de la vida entre estudiantes de diversos programas de estudio; La importancia práctica del estudio consistió en compilar un bloque de técnicas de psicodiagnóstico que pueden usarse para diagnosticar tanto las orientaciones de la vida de una persona como la esfera del significado del valor. Además, sobre la base de los datos obtenidos, es posible desarrollar un soporte correctivo para las orientaciones de la vida y las características personales individuales relacionadas de la persona.

Palabras clave: Análisis teórico; Orientaciones de vida de una persona; Modelo situacionalmente integral de la personalidad de una persona; Orientaciones sujeto-objeto: Plan de vida inconsciente.

\section{Introduction}

Life orientations of an individual is not only a psychological, but also a philosophical and sociological concept. It embraces the totality of typical types of life of an individual or a social group. Let us turn to foreign studies: to the scenario approach developed by E. Berne. E. Berne (2004) implies under the script the "unconscious life plan", which is made up in childhood, reinforced by parents, justified by the course of events and reaches a peak when 
choosing a life path. This group of theories connects life orientations with the presence of an individual's internal picture of life activity, a scenario that directs the activity of the subject.

As an integrating approach, we will consider the approach of E.Yu. Korzhova (2009) "Subject-object orientation in life situations as a factor in the relationship of the external world of man and intrapsychic organization" (Korzhova, 2009). E.Yu. Korzhova (2009) developed the methodology "Questionnaire of subject-object orientations in life situations", which also became one of the tools in our study.

Four basic indicators have been identified as a measurement of subject-object orientations in the process of creating and psychometric justification of the corresponding methodological tools. The adjective "trans-situational" is included in their name. This term is used to describe individual characteristics of a person's interaction with life situations. As a result of the factor analysis, an updated model of subject-object orientations was adopted, including four factor scales:

1. Trans-situational variability - how a person interacts with a life situation - changing or stabilizing.

2. Trans-situational locus of control - who carries out the interaction of a person with a life situation: he or other people, external circumstances.

3. Trans-situational orientation of the world development - where, in what direction, the interaction of a person with a life situation takes place - inward or outward.

4. Trans-situational mobility - where, under what conditions life activity is carried out: in familiar or in new life situations.

A "subjective" orientation is characterized by an internal determination of life. Man demonstrates himself as a subject. A "subjective" orientation is characterized, according to our data, by the severity of such qualities as flexibility, general internality, internality in the field of achievements and failures, as well as the breadth of the time perspective, accompanied by a "feeling of joyous fullness of life."

\section{Materials And Methods}

Our research was based on E.Yu. Korzhova's (2009) theory in the framework of which life orientations are considered as a general determinant of the life of an individual. We examined the specific features of professional self-determination and the specific relationship between different professional groups and their characteristic individual-personal 
characteristics: regulatory, value and cognitive. The sample of the study was 180 students from the Faculty of Humanities, the Faculty of Physical Culture and Sports, and the Faculty of Physics and Mathematics.

\section{Results And Discussion}

Based on the results of a comparative analysis of life orientations among students of various programs, it can be assumed that students of the Faculty of Humanities have high levels of trans-situational variability ( $\bar{X}=38)$, trans-situational development of the world $(\bar{X}=36,6)$, and trans-situational creativity ( $\bar{X}=36,1)$. The indicator of the trans-situational development of the world was at a high level among students of technical programs $(\bar{X}=22.6)$. The indicators of the trans-situational locus of control $(\bar{X}=30,6)$, as well as the trans-situational mobility ( $\bar{X}$ $=31,6)$ were at an average level of expressiveness among students doing technical courses. Students of the Faculty of Physical Culture and Sports have a high indicator on the scale of the trans-situational locus of $\operatorname{control}(\overline{\mathrm{X}}=32)$, the indicators of the trans-situational variability ( $\overline{\mathrm{X}}$ $=26)$ and trans-situational mobility $(\bar{X}=28,6)$ are expressed at an average level. But they have a low level in comparison with other groups on the scale of the trans-situational creativity ( $\bar{X}$ $=21,2)$.

Thus, the following differences were found in the characteristics of the life orientations among students of various programs of study. Students of the Faculty of Humanities, unlike the other two groups, have a higher desire for self-knowledge, improvement of their inner world, and moral growth. The average level of expressiveness among students of the Faculty of Physical Culture and Sports on the scale of orientation in the world development suggests that they may have a feeling of complete control over their lives, but they do not deny the important role of external events. The indicator of the trans-situational creativity is highly expressed among students of the Faculty of Humanities, which characterizes them as creative, seeking to search for new ideas, innovations.

Proceeding from the results of assessing the meaning of life orientation, we can assume what values underlie the life orientations of students of various programs. The scale of material values at an average level is expressed among students of the Faculty of Humanities $(\bar{X}=18)$ and students of the Faculty of Physical Culture and Sports $(\bar{X}=16)$. The low level on this scale 
is among students of the Faculty of Physics and Mathematics $(\bar{X}=2)$. Social values are at a high level in students of the Faculty of Physical Culture and Sports $(\bar{X}=24)$, the average level of expression for the Faculty of Humanities $(\bar{X}=20)$ and lower than that of other groups among physicists and mathematicians $(\bar{X}=15)$. Spiritual values for all three groups are expressed at an average level: for students of humanities $(\bar{X}=14)$, among the students of the Faculty of Physical culture and Sports $(\bar{X}=16)$, for the Faculty of Physics and Mathematics $(\bar{X}=13)$.

Thus, students of the Faculty of Physics and Mathematics are less materially oriented; for other groups, material values are supposedly not the key ones, guiding both in choosing a profession and in life orientations as a whole, but they occupy not the last place in the personality's value system. Social values are most important for students of the Faculty of Physical Culture and Sports. We can assume that friendship, love, and family are of great value in the lives of these students. But the spiritual values of all groups are expressed at an average level.

Based on the indicators of life orientations, we determine that the students of the Faculty of Physical Culture and Sports are the least satisfied with the process of life, its interest and emotional richness. The indicators on this scale are highly expressed among the students of the Faculty of Humanities ( $\bar{X}=38,8$ ), which characterizes them as people who live for the day. The indicator of purpose in life of all three groups is not very different and is expressed at a fairly high level, which indicates the students' purposefulness. They give meaningfulness, orientation and time perspective to life. Students of the Faculty of Physical Culture and Sports $(\bar{X}=34,5)$, have the highest goal achievement in life or satisfaction with self-realization, despite the fact that at the moment they are not considering their life emotionally rich and interesting. We can assume that they see the stage of vocational training as a way out to success and self-realization, but they assess their past as quite successful. The Faculty of Physics and Mathematics has also this indicator quite highly expressed $(\bar{X}=32,4)$. The students of the Faculty of Humanities give lower assessments than others of their past achievements on the path to success ( $\bar{X}=25,3)$, although now their life seems to them quite rich and interesting.

In all three groups the indicators of the locus of control-I and the locus of control of life are expressed at an equally high level. 


\section{Life Views among Students of Various Programs of Study}

Students of the Faculty of Humanities see their life path as the most difficult ( $\bar{X}=40$ ), besides, this life path is not multi-alternative, which becomes the cause of the greatest costs for choosing an alternative and personal resources in comparison with other groups. Significant differences between humanities students and other programs were identified on the scale of the trans-situational creativity $(\mathrm{U}=210.5$, at $\mathrm{p}<0.1)$. It can be assumed that these students are most creative in their approach, unlike others, without planning their affairs in advance, which is also the specific feature of their professional activity.

\section{The Assessment of the Process of Life, Interest and Emotional Richness}

Significant differences between students at the Faculty of Humanities and students at the Faculty of Physical education and Sports $(U=242$, at $\mathrm{p}<0.01)$. It can be assumed that students of the Faculty of Physical Culture and Sports focus on future successes, considering this moment of their life to be only a stage to achievements, and students of the Faculty of Humanities live for the day, which is possibly associated with the idea of their life as an eventful process that brings discoveries every day.

Significant differences in terms of intelligence development are observed among students of the Faculty of Humanities and students of physical education and sports ( $U=242$, at $\mathrm{p}$ <0.01). This factor is not aimed at determining the level of intelligence, it is focused on measuring the efficiency of thinking and the general level of verbal culture and erudition. Students of the Faculty of Humanities can be characterized as possessors of a fairly high general culture and erudition, developed abstract thinking, which can be attributed to the professionally important qualities of specialists working in the "person-to-person" system, but students of the Faculty of Physical Culture and Sports, although they enter into the process of communication, since they are teachers, they are still more focused on solving practical problems (Masalimova \& Shaidullina, 2017).

\section{Conclusions}

1. Humanities students are distinguished by the highest indices of the trans-situational variability, which characterizes them as people who seek to learn new things in the world around them. 
2. The trans-situational locus of control among students of all programs of study is expressed at an average level, which indicates a similar responsible attitude of students to the events of their life, their own actions and their consequences.

3. Students of the Faculty of Physical Culture and Sports strive for self-realization in the outside world. This is accompanied by the perception of one's life as rich in external events, control over one's own life. Humanities students are more focused on their inner world, striving for moral growth and self-improvement. Students of the Faculty of Physical Culture and Sports are the least creative individuals. Their program requires solving practical problems rather than a creative approach to business (Masalimova et al., 2019; Salakhova et al., 2018b; Mitin, 2016; Kalenik et al., 2018).

The results of the study of the value-meaning sphere suggest that: the students of the Faculty of Physics and Mathematics are the least materially oriented, and their social and spiritual values are at an average level, which can be associated with the specific features of their professional activity in the system "person-sign”. Material values are at an average level among the students of the Faculty of Humanities and the Faculty of Physical Culture and Sports, and the highest indicator of social values is among the students of the Faculty of Physical Culture and Sports, which characterizes their focus on such life values as family, friendship. The goal achievement in life or satisfaction with self-realization is the highest among students of the Faculty of Physical Culture and Sports, despite the fact that at the moment they are not considering their lives emotionally rich and interesting. We can assume that they see the stage of vocational training as a way out to success and self-realization, but they assess their past as quite successful. This indicator is also quite highly expressed among the students of the Faculty of Physics and Mathematics. In all three groups, the indicators of the locus of control-I and the locus of control over life were expressed at an equally high level (Masalimova et al., 2014; Salakhova et al., 2018c).

Comparison results of individual-personal characteristics (emotional and regulatory sphere, intelligence, imagination, normativity): the students of the Faculty of Physics and Mathematics are the most emotionally stable, and students of the Faculty of Humanities are most prone to introspection; students of all programs have an average level of normativity, which characterizes them as responsible, observing generally accepted norms and rules. Features of the emotional-volitional sphere (perseverance, organization) allow them to be successful in those professional areas that they have chosen, since the role of self-regulation is quite high for each of the professional areas we are studying; a high intelligence level among 
students of humanities is indicative of their developed abstract thinking, responsiveness, quick wit, and quick learning. A sufficiently high level of general culture, especially verbal, which is very important for representatives of the group of "human-human" programs which students of the Faculty of Humanities belong to; students of the Faculty of Physics and Mathematics and the Faculty of Physical Culture and Sports can be described as realistic, attentive, focused, able to quickly solve practical problems, and students of the Faculty of Humanities can operate more easily with abstract concepts than others (Mitin et al., 2018; Masalimova \& Chibakov, 2016; Kalinina et al., 2018; Salakhova et al., 2018a).

\section{Recommendations}

Based on the conclusions, we can give the following practical recommendations for the psychological support of students at the stage of training:

1. The formation of students' internal readiness for conscious, independent adjustments, construction and implementation of the prospects for personal and professional development.

2. Assistance in harmonizing personal and professional values.

3. Emotional support for building self-confidence.

\section{Acknowledge}

This publication was prepared with the financial support of the Grant of the President (MK-2074.2019.6).

\section{REFERENCES}

1. Berne, E. (2004). Transactional analysis: per. from English. Moscow: Acad. Project.

2. Kalenik, E. N., Salakhova, V. B., Mikhaylovsky, M. N., Zhelezniakova, M. E., Bulgakov, A. V. \& Oshchepkov, A. A. (2018). Psychophysiologic features and personal-adaptive potential of students with limited abilities. Electronic Journal of General Medicine; 15(6): em98

3. Kalinina, N. V., Zaretskiy, V. V., Salakhova, V. B., Artamonova, E. G., Efimova, O. I. \& Lekareva, E. E. (2018). Psychological and Pedagogical Resources of Security Provision and Prevention of Internet Risks and Life Threats Among Children and 
Teenagers in the Educational Environment. Modern Journal of Language Teaching Methods, 8(8), 118-129.

4. Korzhova, E.U. (2009). Psychology of personality. Teaching aid for practical lessons. St.Petersburg: Publishing house ANO "API".

5. Masalimova, A. R. \& Chibakov, A. S. (2016). Experimental analytical model of conditions and quality control of vocational training of workers and specialists. Mathematics Education, 11(6), 1796-1808.

6. Masalimova, A. R., Mikhaylovsky, M. N., Grinenko, A. V., Smirnova, M. E., Andryushchenko, L. B., Kochkina, M. A. \& Kochetkov, I. G. (2019). The interrelation between cognitive styles and copying strategies among student youth. Eurasia Journal of Mathematics, Science and Technology Education, 15(4), em1695.

7. Masalimova, A. R., Schepkina, N. K., Leifa, A. V., Shaidullina, A. R., Burdukovskaya, E. A. (2014). Mentoring perfection in modern enterprises conditions: practical recommendations. American Journal of Applied Sciences, 11(7), 1152-1156.

8. Masalimova, A. R. \& Shaidullina, A. R. (2017). Diversification of Professional Onthe-Job Training Models and Forms in Contemporary Business Conditions. Modern Journal of Language Teaching Methods, 7(3), 554-561.

9. Mitin, S. N. (2016). Psychotherapeutic approach in the management of the development of educational systems. Simbirsk Scientific Bulletin, 4(26), 31-39.

10. Mitin, S. N., Kidinov, A. V., Fedotov, S. N., Leontev, M. G., Bolotova, A. K. \& Kalinin, I. V. (2018). A Modern Models of Career Readiness. Modern Journal of Language Teaching Methods, 8(3), 68-75.

11. Salakhova, V. B., Belinskaya, D. B., Erofeeva, M. A., Ulyanova I. V., Zotova, L. E., Khammatova, R. S. \& Mizonova, O. V. (2018a). Modern methods of diagnosing addiction to psychoactive substances: neurophysiological aspects. Electronic Journal of General Medicine, 15(6), 94-106.

12. Salakhova, V. B., Sidyacheva, N. V., Zotova, L. E., Klepach, Y. V., Rusyaeva, T. A., Belova, T. A. \& Buevich, S. Y. (2018b). Specific Features of Normative Ideals and Individual Priorities of the Deviant Personality. Modern Journal of Language Teaching Methods, 8(5), 232-242.

13. Salakhova, V. B., Zaretskiy, V. V., Kalinina, N. V., Artamonova, E. G., Efimova, O. I. \& Lekareva, E. E. (2018c). Existential Psycho-Correction of the Value-Meaning Sphere of the Personality of Adolescents with Deviant Behavior. Modern Journal of Language Teaching Methods, 8(6), 294-302. 


\section{SOBRE OS AUTORES:}

\section{Galina S. Goloshumova}

Doctor of Education, Professor, Department of pop-jazz art, Moscow Pedagogical State University, Moscow, Russia. E-mail: g-gs@mail.ru

iD http://orcid.org/0000-0002-8268-9694

\section{Olga V. Gribkova}

Doctor of Education, Professor, Department of Music Art, Moscow City University, Moscow, Russia. E-mail: Groli@ mail.ru

(iD) http://orcid.org/0000-0001-8553-8675

\section{Alexey V. Kidinov}

Doctor of Psychology, Professor, Faculty of Communication Management, Russian State Social University, Moscow, Russia. E-mail: a080ak@gmail.com

(iD) http://orcid.org/0000-0001-5122-9616

\section{Muliat M. Tkhugo}

$\mathrm{PhD}$ in Pedagogy, associate professor, Department of State Municipal Management Law and Psychology, Moscow Aviation Institute MAI (National Research University), Moscow, Russia. E-mail: tkhugo@mail.ru

(iD) http://orcid.org/0000-0002-7565-8259

\section{Oxana E. Chernova}

$\mathrm{PhD}$ in Pedagogy, associate professor, Academy of Engineering, RUDN University, Moscow, Russia. E-mail: oxana-c@ mail.ru

(iD) http://orcid.org/0000-0001-6053-9014

\section{Natalia N. Telysheva}

PhD in Pedagogy, associate professor, Directorate of Educational Programs, Moscow City University, Moscow, Russia. E-mail: nnteln@gmail.com

iD http://orcid.org/0000-0001-6606-9849

\section{Emilia R. Agadzhanova}

Senior Lecturer, Faculty of Humanities, Ulyanovsk State University, Ulyanovsk, Russia. Email: emilia73.90@mail.ru

iD http://orcid.org/0000-0002-0132-1805 